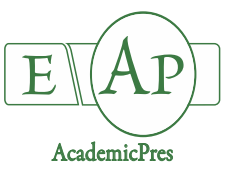

Marcu N et al. (2020)

Notulae Botanicae Horti Agrobotanici Cluj-Napoca 48(2):783-798

DOI: $10.15835 /$ nbha 48211874

Research Article

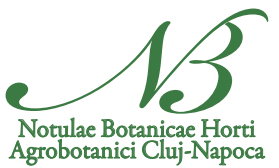

\title{
Vineyards' restructuring and conversion through national support programmes - the case of Romania
}

\author{
Nicu MARCU ${ }^{1}$, Georgeta-Madalina MEGHISAN-TOMA ${ }^{2 *}$, \\ Georgiana-Raluca LADARU ${ }^{3}$, Carmen-Elena DOBROTA ${ }^{4}$
}

\author{
${ }^{1}$ Bucharest University of Economic Studies, 5-7 Mihail Moxa, County 1, 010961, Bucharest, Romania; Romanian Academy, Institute of \\ National Economy, 13 Calea 13 Septembrie, County 5, Bucharest, Romania; nicu.marcu@eam.ase.ro \\ ${ }^{2}$ Bucharest University of Economic Studies, Faculty of Business Administration in foreign languages, 2-2A Calea Grivitei, County 1, \\ 010731, Bucharest, Romania; Romanian Academy, National Institute of Economic Research "Costin C. Kiritescu”, 13 Calea 13 \\ Septembrie, County 5, Bucharest, Romania; madalina.meghisan@fabiz.ase.ro (*correspondingauthor) \\ ${ }^{3}$ Bucharest University of Economic Studies, Faculty of Agrifood and Environmental Economics, 5-7 Mihail Moxa, County 1, 010961, \\ Bucharest,Romania; raluca.ladaru@eam.ase.ro \\ ${ }^{4}$ University of Bucharest, Faculty of Business and Administration, 4-12 B-dul Regina Elisabeta, County 3, 030018, Bucharest, Romania; \\ Romanian Academy, Institute of National Economy, 13 Calea 13 Septembrie, County 5, Bucharest, Romania; \\ carmen.dobrota@faa.unibuc.ro
}

\begin{abstract}
Wine industry is considered to be a traditional industry, where the potential for growth is still important for the existing wine producers and new entrants, based on strategies for increasing international awareness, technological innovation and financing programmes. The paper aims to explore the evolution of the determinants of wine and vineyards industry from a macroeconomic perspective, in order to assess the efficiency of the National Support Programmes, financed under the European Union funds. The exploration intends to cover the tendency of the following indicators: areas under vines, areas under vines for wines, wine producers, wine consumers, wine imports and wine exports, in order to explore new opportunities for growth and develop future orientation. Moreover, the analysis intends to address the importance of National Support Programmes 2009-2013; 2014-2018; 2019-2023, whose evolution is currently considered a key research question in the field. Romania is an important European country from the point of view of wine industry, the various wines it produces are known for their quality. With an area of around 180,000 ha cultivated with vines which, in 2016, represented $1.42 \%$ of its agricultural area and $2.28 \%$ of arable area, Romania ranks the $5^{\text {th }}$ position in the European Union, after Spain, Italy, France and Portugal. However, the countries that took advantage of the financial funds allocated to the National Support Programmes, were: Italy, Spain and France, which together spent more than $70 \%$ of the total amount for each of these programmes.
\end{abstract}

Keywords: hybrid vines; National Support Programme; vineyards; vines; wine; wine consumers; wine producers 


\section{Introduction}

Wine industry is considered to be a traditional industry, where the potential for growth is still important for the existing wine producers and new entrants, based on strategies for increasing international awareness, technological innovation and financing programmes. Also, small and medium enterprises (SMEs) can play an important role to the development of this industry, mainly based on the "diffusion of wine innovation" (Menna and Walsh, 2019).

The paper aims to explore the evolution of the determinants of wine and vineyards industry from a macroeconomic perspective, in order to assess the efficiency of the National Support Programmes, financed by the European Union. The exploration intends to cover the tendency of the following indicators: areas under vines, areas under vines for wines, wine producers, wine consumers, wine imports and wine exports, in order to explore new opportunities for growth and develop future orientation. Moreover, the analysis intends to address the importance of National Support Programmes 2009-2013; 2014-2018; 2019-2023, whose evolution is currently considered a key research question in the field.

Several studies were conducted in the field of wine consumption and production, especially focused on the effects of the economic crisis that affected the evolution of this industry. One of the main effects presented by Andreyeva et al. (2010), Casini et al. (2014), Samoggia et al. (2014) is the decline in purchases in terms of "food quantity and quality" and an increase in "sales of low-cost products". A research focused on the crisis' impact on the Greek market revealed that consumers "preferred less expensive products characterised by prime prices" (Duquenne and Vlontzos, 2014). On the other hand, Asgeirsdottir et al. (2014) pointed out that in Iceland the economic crisis had a positive effect, "favouring health-promoting behaviours". In the wine industry, two phenomena could be observed (Anderson and Nelgen, 2011; Hammorvoll et al., 2014): "the increase of mass-produced wine" and "the specialisation towards narrow markets". These aspects can be explained by the "polarisation of consumers towards opposite behaviours" (Contini et al., 2015).

The main factors that have an influence on the wine demand are (Vlachos, 2017): "price in conjunction with disposable income", "dietary habits of consumers", "seasonality", "tourism and local traditions/festivities". Other studies focused on the "wine attributes" that influence consumer purchasing behaviour" (Goodman $e t$ al., 2008), followed by price as a sign of quality (Jover et al., 2004), especially for the consumers "who have a low involvement with wine" (Hollebeek et al., 2007). On the other hand, the consumers that are loyal to the brand "stock up on their favourite brand during promotional sales and wait for another promotional sale of the brand” (Ritchie et al., 2010).

Other authors underlined the importance of "continuous analyses and monitoring of land use" for vineyards (Fikfak et al., 2017), due to the fact that "high erosion rates are being recorded" (Prosdocimi et al., 2016). However, the influences on the quantity and the quality of grapes came from several factors (Rotaru $e t$ al., 2010): "climate”, "soil”, “topography", "micro-climate”, "human factors genetics", "environmental and technological factors" etc.

The paper is organized as follows. The "Materials and Methods" section gives a background of the wine and vines industry, by presenting the evolution of the appropriate indicators at a worldwide level, followed by the same analysis at the level of the European Union's countries and taking as example the case of Romania, one of the players with potential for development and growth in this field. The main focus in this section will be on: areas under vines; wine production and consumption. The "Results and discussions" relates the competitiveness growth linked to the National Support Programmes 2009-2013; 2014-2018; 2019-2023, from the perspective of new opportunities in the wines and vine industry. The "Conclusions" section discusses the findings and underlines the conclusions and limits of the research. 


\section{Materials and Methods}

\section{Areas under vines}

The aim of the study is the exploration of wine and vineyards' related indicators in order to assess the efficiency of National Support Programmes, financed by the European Unions' funds.

At the worldwide level, the total area under vines had an oscillatory dynamic with a decreasing trend, from 7,594 million ha in 2007 to 7,454 million ha in 2016 (International Organisation of Vine and Wines, 2019). Europe represents the largest continent regarding the area under vines, representing a percentage between $48.88 \%-55.01 \%$ from the total area under vines (Table 1 ).

Table 1. Areas under vines at the worldwide level - ha [2007-2018]

\begin{tabular}{|c|c|c|c|c|c|c|}
\hline Year & Worldwide & Africa & America & Asia & Europe & Oceania \\
\hline 2007 & 7,594 & 0,381 & 0,993 & 1,838 & 4,178 & 0,204 \\
\hline 2008 & 7,533 & 0,379 & 1,004 & 1,821 & 4,122 & 0,207 \\
\hline 2009 & 7,49 & 0,368 & 1,017 & 1,867 & 4,024 & 0,213 \\
\hline 2010 & 7,479 & 0,369 & 1,025 & 1,956 & 3,921 & 0,208 \\
\hline 2011 & 7,462 & 0,375 & 1,035 & 2,02 & 3,824 & 0,207 \\
\hline 2012 & 7,473 & 0,379 & 1,045 & 2,082 & 3,766 & 0,2 \\
\hline 2013 & 7,506 & 0,378 & 1,06 & 2,149 & 3,723 & 0,195 \\
\hline 2014 & 7,551 & 0,376 & 1,067 & 2,214 & 3,703 & 0,192 \\
\hline 2015 & 7,507 & 0,378 & 1,063 & 2,21 & 3,67 & 0,186 \\
\hline 2016 & 7,454 & 0,383 & 1,052 & 2,157 & 3,678 & 0,183 \\
\hline
\end{tabular}

Source: International Organisation of Vine and Wines, 2019

At the worldwide level, Peru registered the highest growth of vineyards, from 25,000 ha in 2014 to 32,000 ha in 2018. Mexico registered a growth of $24 \%$ regarding the spread of vineyards, from 29,000 ha in 2014 to 37,000 ha in 2018.

On the other hand, the highest decrease in vineyards was represented by Iran with -29\%, in 2018 (153,000 ha) compared to 2014 (216,000 ha). Ukraine also registered a decrease in vineyards area with $-14 \%$ in 2018 (42,000 ha) compared to 2014 (49,000 ha) (Figure 1).

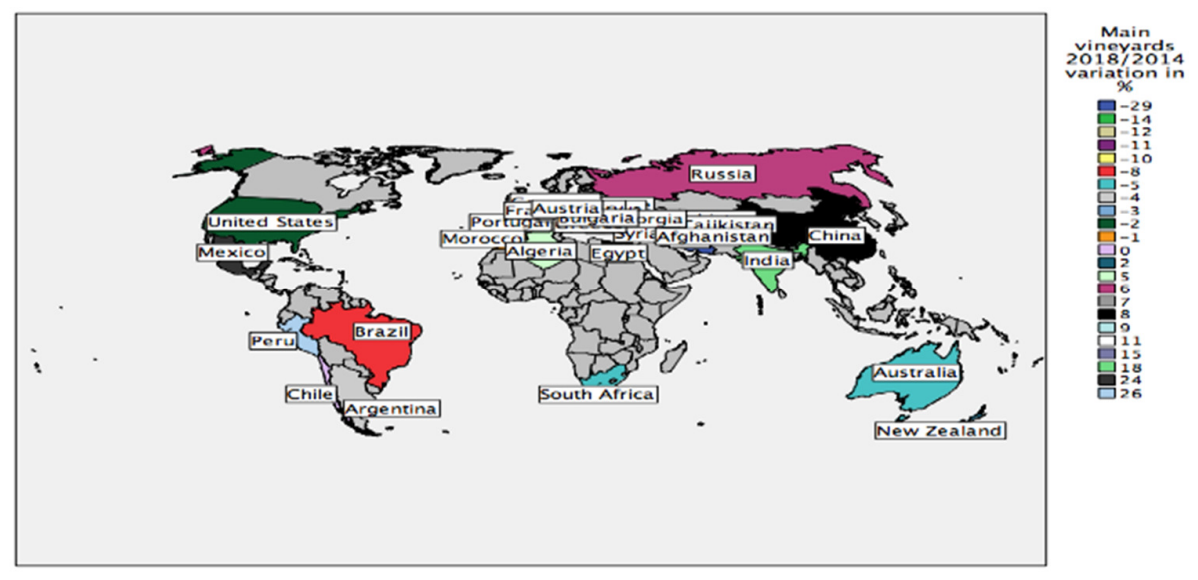

Figure 1. Main vineyards at the worldwide level 2018/2014 [\%]

Source: Authors' own processing with SPSS 20.00 software for Windows

Making the same analysis at the level of the European Union, regarding the area under vines, the decrease rate in vineyards is reduced significantly. Thus, the area under vines was reduced with 129,948 ha $(3.88 \%)$ during the period 2010-2019 (Table 2). 
Table 2. Areas under vines in European Union's countries - ha [2010-2019]

\begin{tabular}{|c|c|c|c|c|c|c|c|c|c|c|}
\hline State & 2010 & 2011 & 2012 & 2013 & 2014 & 2015 & 2016 & 2017 & 2018 & 2019 \\
\hline Bulgaria & 75,591 & 68,847 & 60,328 & 60,299 & 59,701 & 59,988 & 60,418 & 60,583 & 61,251 & 60,862 \\
\hline Czechia & 17,361 & 17,471 & 17,366 & 17,480 & 17,631 & 17,673 & 17,623 & 17,720 & 16,811 & 18,038 \\
\hline Germany & 102,692 & 102,671 & 102,598 & 102,810 & 102,856 & 102,858 & 102,752 & 102,727 & 102,939 & 103,173 \\
\hline Greece & 67,851 & 67,333 & 66,474 & 65,330 & 65,020 & 64,013 & 62,773 & 62,728 & 62,804 & 63,181 \\
\hline Spain & $1,018,655$ & 968,298 & 953,177 & 957,753 & 958,778 & 958,696 & 959,534 & 951,946 & 955,377 & 950,079 \\
\hline France & 816,042 & 806,242 & 807,600 & 804,831 & 804,297 & 805,780 & 793,905 & 810,075 & 810,850 & 811,923 \\
\hline Croatia & & & & & 26,761 & 21,310 & 20,855 & 20,339 & 20,482 & 20,081 \\
\hline Italy & 673,325 & 663,905 & 654,823 & 646,485 & 641,744 & 636,274 & 645,800 & 652,217 & 657,708 & 666,421 \\
\hline Cyprus & 10,109 & 9,066 & 8,605 & 8,417 & 7,871 & 7,806 & 7,908 & 7,873 & 7,711 & 7,673 \\
\hline Hungary & 71,003 & 71,792 & 64,411 & 64,688 & 64,764 & 64,800 & 54,573 & 65,263 & 65,582 & 65,397 \\
\hline Austria & 45,533 & 46,092 & 46,711 & 47,701 & 47,237 & 47,255 & 47,583 & 48,282 & 48,863 & 48,845 \\
\hline Portugal & 236,720 & 236,816 & 233,943 & 226,865 & 221,449 & 201,445 & 193,219 & 191,633 & 190,322 & 192,743 \\
\hline Romania & 181,562 & 181,770 & 183,170 & 182,715 & 182,849 & 182,375 & 182,361 & 182,488 & 182,616 & 183,033 \\
\hline Slovenia & 16,177 & 16,041 & 16,172 & 16,110 & 15,997 & 15,669 & 15,604 & 15,593 & 15,646 & 15,500 \\
\hline Slovakia & 19,634 & 18,971 & 18,705 & 18,512 & 18,046 & 18,437 & 17,598 & 16,610 & 15,415 & 15,358 \\
\hline Total & $3,352,255$ & $3,275,315$ & $3,234,083$ & $3,219,996$ & $3,235,001$ & $3,204,379$ & $3,182,506$ & $3,206,077$ & $3,214,377$ & $3,222,307$ \\
\hline
\end{tabular}

The world production of grapes at the level of the year 2018 was 77.8 million of tones, with $57 \%$ production of wine grapes, $36 \%$ production of table grapes and $7 \%$ of dried grapes. (bttp://www.oiv.int/public/medias/6782/oiv-2019-statistical-report-on-world-vitiviniculture.pdf, accessed on 10.03.2020)

At the level of the European Union's states, analyzing the dynamics of areas under vines for wine, four of 14 countries registered a growth in 2019 compared to 2010: Austria (7.27\%), Czech Republic (3.90\%), Romania $(0.81 \%)$ and Germany $(0.47 \%)$ (Figure 2).

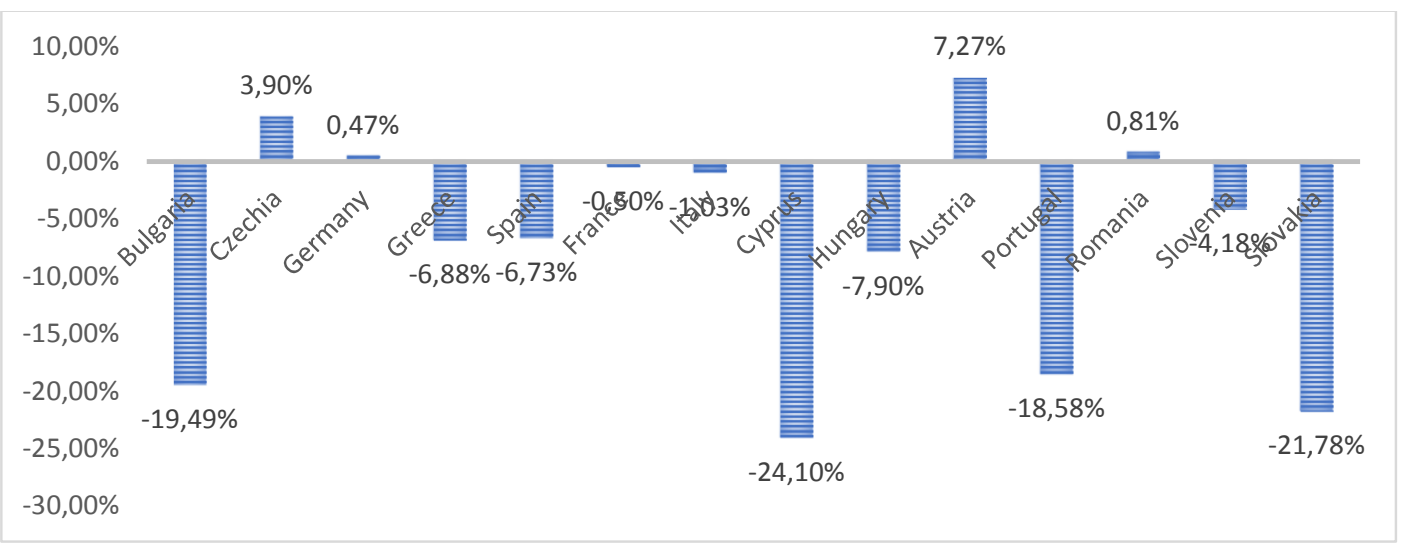

Figure 2. Dynamics of vineyards for wine at the level of European Union 2019/2010 [\%]

Source: DG Agri, https://agridata.ec.europa.eu/extensions/DashboardWine/WineProduction.html, accessed on 12.03.2020

During the analysed period, the world's areas under vines underwent mutations, both in terms of the number of hectares and the assortment structure.

Thus, at the global level, the area under vines in operation is relatively constant. On the other hand, at the E.U. level, there are major differences in surface dynamics. In the first case, the explanation comes from the fact that, if in some parts of Europe, there is a decrease in the areas under vines, in other parts of the world, such as Asia (China, Thailand, Vietnam), there is a concern for growing grapes.

In the case of E.U. countries, the technological development, associated to an increase of the emancipation degree of the population, led to an increase in the consumption preferences for the highest 
quality of wine. Consequently, there have been situations in which, considerable quantities of wine, of medium and below average quality, could not be capitalized, in the case of large wine producing countries. Thus, unsold stocks appeared, which had to be distilled, in order to protect the wine industry and empty the storage space for the new harvest.

Schemes have been set up to support wine producers, by ensuring payments for storage and distillation, together with the commitments of the states to take over stocks of distilled wine. The perpetuation of this situation has led to the creation of agricultural policies through which, Member States provide financing in the form of deforestation premiums for grape-producing vineyards, from which table wines are obtained.

At the same time, financial support was provided for viticulturally reconversion, in the sense of replanting significantly smaller areas of grape varieties under quality wines. Thus, according to the analysis made, the area under vines has decreased by about 130,000 ha at the E.U. level, since 2007.

From a financial point of view, despite the current conditions, the performance of the wine chain has increased, on the one hand, due to the higher price of quality wines and, on the other hand, due to the increase in technology and mechanization, especially in grape production.

\section{Wine production and consumption}

The global wine production at the level of the year 2018 was 292 million of hectoliters. Hungary registered the highest growth of wine production, from 2.4 million hl in 2014 to 3.6 million hl in 2018. Austria registered a growth of $40 \%$ regarding the production of wine, from 2 million hl in 2014 to 2.8 million hl in 2018. Romania registered a growth of $38 \%$ regarding the production of wine, from 3.7 million hl in 2014 to 5.1 million hl in 2018.

On the other hand, the highest decrease in wine production was represented by China with $-33 \%$, in 2018 (9.1 million hl) compared to 2014 ( 13.5 million hl). Greece also registered a decrease in wine production with $-21 \%$ in 2018 (2.2 million hl) compared to 2014 (2.8 million hl) (Figure 3).

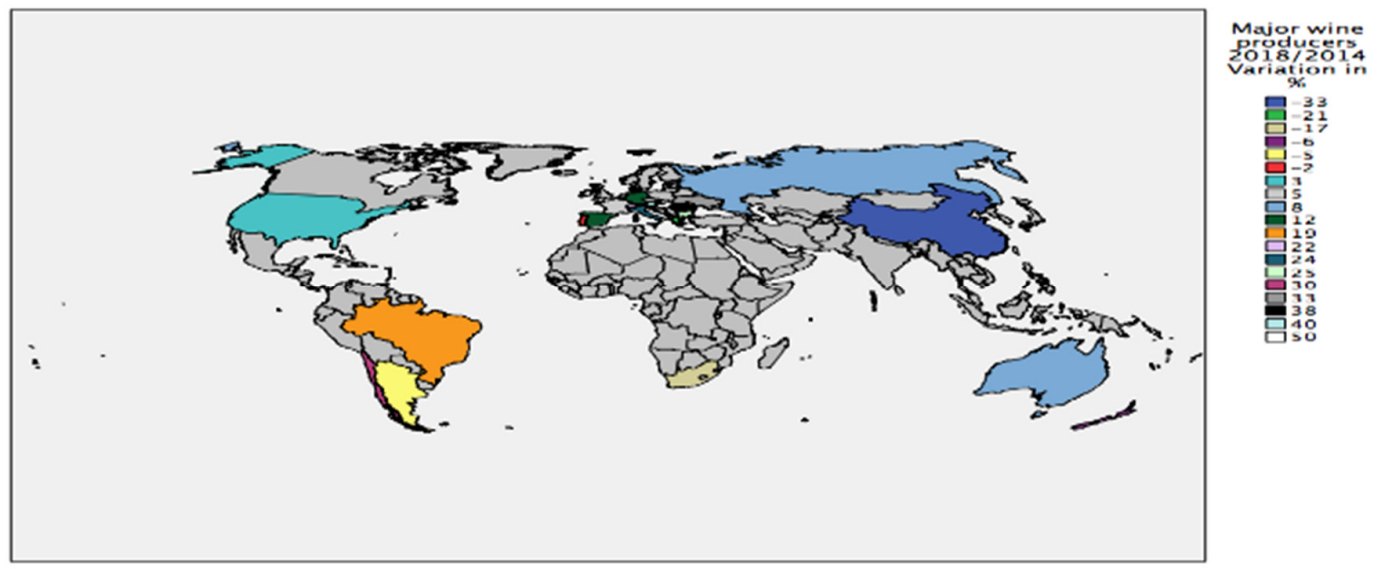

Figure 3. Main wine producers at the worldwide level 2018/2014 [\%]

Source: Authors' own processing with SPSS 20.00 software for Windows

At the level of the European Union, there are several types of vines: wines with Controlled Designation of Origin, wines with Geographical Indication and Varietal wines. Making an analysis of the dynamics of the area under vines for wines with Controlled Designation for Origin, there can be underlined that this area was reduced with 1,279,017 ha (62.04\%) in 2019, compared to 2010 (Table 3).

The areas under vines for wines with Controlled Designation of Origin underwent variations at the level of the European Union's countries in 2019 compared to 2020. Thus, two of the 14 European Union's states had a growth: Austria (7.27\%), Czech Republic (4.18\%) (Figure 4). Also, the proportion of the area under vines for wines with Controlled Designation of Origin in the total underwent variations in 2019 (Figure 5). 
Table 3. Areas under vines for wines with Controlled Designation of Origin, in European Union's countries- ha [2010-2019]

\begin{tabular}{|c|c|c|c|c|c|c|c|c|c|c|}
\hline State & $\mathbf{2 0 1 0}$ & $\mathbf{2 0 1 1}$ & $\mathbf{2 0 1 2}$ & $\mathbf{2 0 1 3}$ & $\mathbf{2 0 1 4}$ & $\mathbf{2 0 1 5}$ & $\mathbf{2 0 1 6}$ & $\mathbf{2 0 1 7}$ & $\mathbf{2 0 1 8}$ & $\mathbf{2 0 1 9}$ \\
\hline Bulgaria & 29,664 & 27,017 & 15,082 & 15,095 & 15,284 & 15,355 & 2,519 & 2,729 & 3,155 & 2,746 \\
\hline Czechia & 17,169 & 17,313 & 17,240 & 17,359 & 17,515 & 17,557 & 17,500 & 17,603 & 15,442 & 17,887 \\
\hline Germany & 102,660 & 102,626 & 102,553 & 102,766 & 102,807 & 102,819 & 102,696 & 65,670 & 65,881 & 69,212 \\
\hline Greece & 13,114 & 13,086 & 12,047 & 11,355 & 11,230 & 12,227 & 12,318 & 12,311 & 12,330 & 12,527 \\
\hline Spain & 861,948 & 821,396 & 813,470 & 827,489 & 828,756 & 340,184 & 384,059 & 386,565 & 323,942 & 322,237 \\
\hline France & 526,700 & 519,642 & 520,385 & 516,383 & 514,432 & 514,003 & 508,742 & 514,505 & 595,193 & 84,338 \\
\hline Croatia & 0 & 0 & 0 & 0 & 14,813 & 18,991 & 18,722 & 18,575 & 18,123 & 17,814 \\
\hline Italy & 274,653 & 284,579 & 314,627 & 335,759 & 341,070 & 344,741 & 120,728 & 91,712 & 82,152 & 89,792 \\
\hline Cyprus & 1,034 & 941 & 936 & 690 & 616 & 0 & 0 & 0 & 0 & 0 \\
\hline Hungary & 33,596 & 31,878 & 51,199 & 46,430 & 46,652 & 53,480 & 43,436 & 50,934 & 306 & 302 \\
\hline Austria & 45,533 & 46,092 & 46,711 & 47,701 & 47,237 & 47,255 & 47,583 & 48,282 & 48,863 & 48,845 \\
\hline Portugal & 96,184 & 94,390 & 92,976 & 84,255 & 80,133 & 78,831 & 84,408 & 83,861 & 84,525 & 86,529 \\
\hline Romania & 25,968 & 27,717 & 28,386 & 30,147 & 31,532 & 2,786 & 2,754 & 3,279 & 3,375 & 302 \\
\hline Slovenia & 16,177 & 16,041 & 16,172 & 16,110 & 15,997 & 0 & 15,466 & 15,452 & 15,502 & 15,362 \\
\hline Slovakia & 17,227 & 16,919 & 16,886 & 16,771 & 16,484 & 17,578 & 16,739 & 15,890 & 14,699 & 14,717 \\
\hline Total & $2,061,627$ & $2,019,637$ & $2,048,670$ & $2,068,310$ & $2,084,558$ & $1,565,807$ & $1,377,670$ & $1,327,368$ & $1,283,488$ & 782,610 \\
\hline
\end{tabular}

Source: DG Agri, https://agridata.ec.europa.eu/extensions/DashboardWine/WineProduction.html, accessed on 12.03.2020

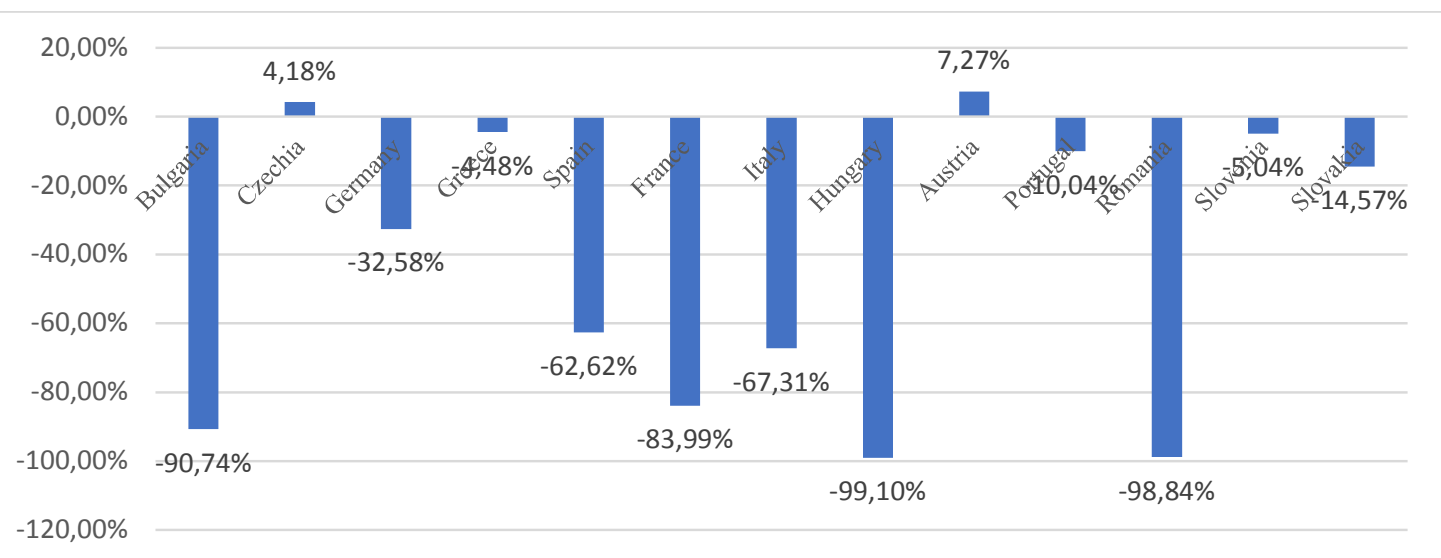

Figure 4. Main vineyards for wines with Controlled Designation of Origin in European Union 2019/2010 [\%]

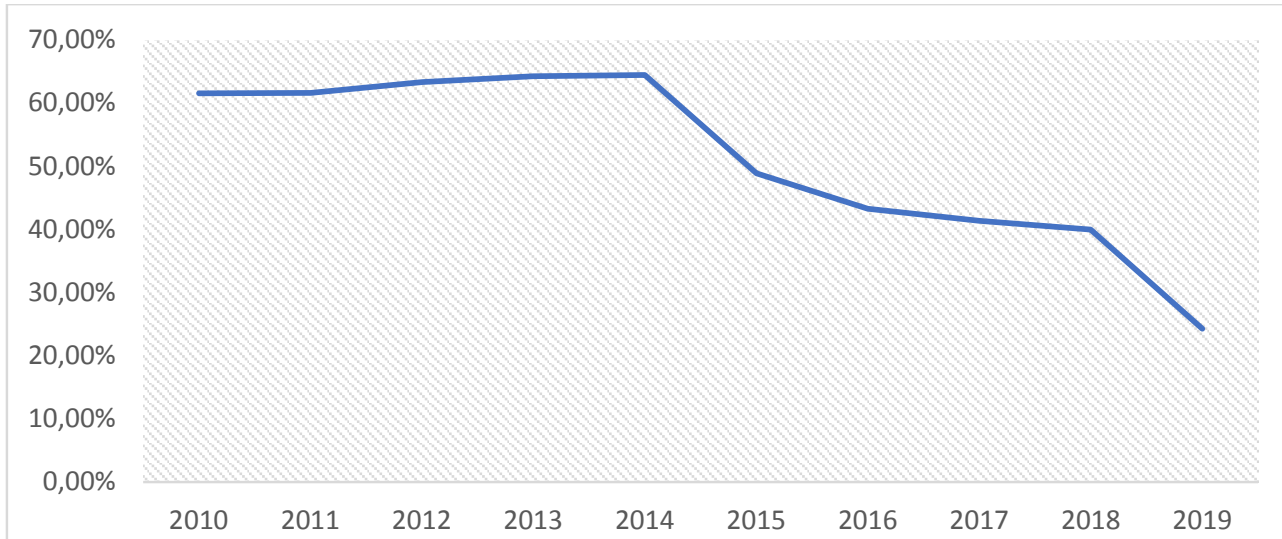

Figure 5. Dynamics of main vineyards for wines with Controlled Designation of Origin in European Union 2019 [\%]. Source: DG Agri, https://agridata.ec.europa.eu/extensions/DashboardWine/WineProduction.html, accessed on 12.03.2020 
In Romania, based on the degree of quality and ripeness of the grapes, the wines can be (bttps://domeniulbogdan.ro/blog/cum-clasificam-vinurile-si-ce-soiuri-de-struguri-sunt-cele-mai-cautate/):

- Table wines, with an alcoholic strength between 8.5 and 9.55. These wines are intended for current consumption.

- Wines of superior quality, which have on the label the following notations: VS, IG or VSIG- with reference to the geographical origin, as well as the mention of the grape variety from which they were produced. They have an alcoholic strength of at least $9.5 \%$.

- Wines with controlled designation of origin represent the wines DOC of the first quality, with a strength of at least $11 \%$ and a sugar content of 190 grams per liter. At the same time, these can also be wines of controlled designation of origin by steps of quality (DOCC).

The global wine consumption at the level of the year 2018 was 246 million of hectoliters. Portugal registered the highest growth of wine consumption, from 4.3 million $\mathrm{hl}$ in 2014, to 5.5 million $\mathrm{hl}$ in 2018 . Mexico registered a growth of $28.6 \%$ regarding the wine consumption, from 0.9 million hl in 2014 to 1.2 million hl in 2018.

On the other hand, the highest decrease in wine consumption was registered in Chile with $-22.2 \%$, in 2018 ( 2.3 million $\mathrm{hl}$ ) compared to 2014 ( 3.0 million $\mathrm{hl}$ ). Austria also registered a decrease in wine consumption with $-22.2 \%$ in 2018 (2.3 million hl) compared to 2014 (3.0 million hl) (Figure 6).
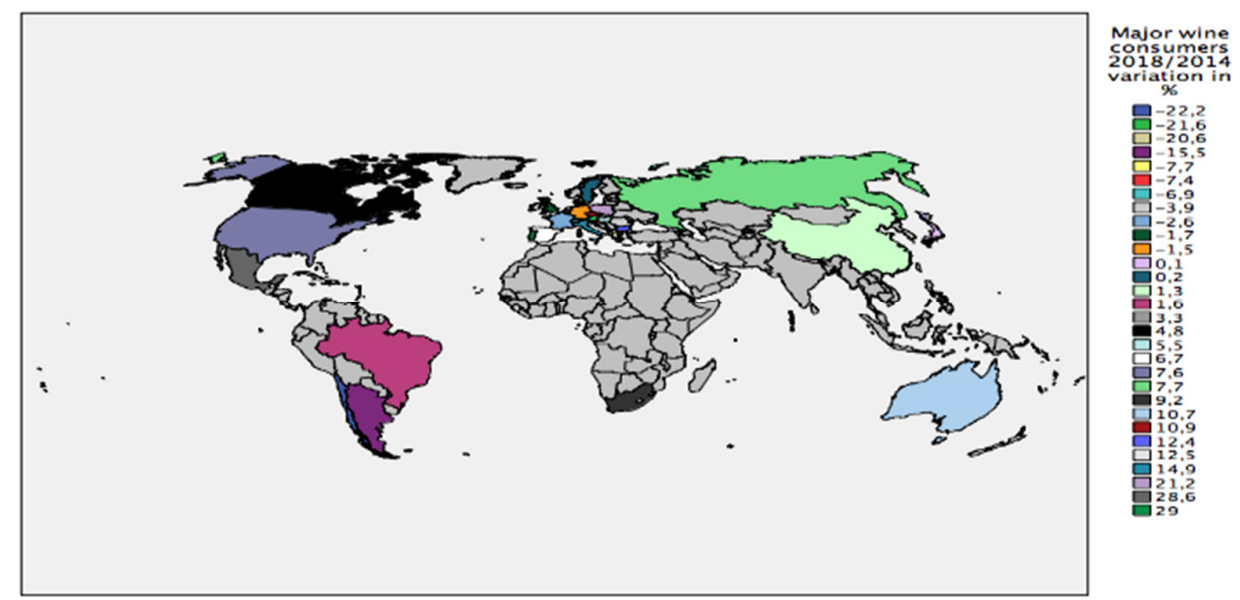

Figure 6. Major wine consumers at the worldwide level 2018/2014 [\%]

Source: Authors' own processing with SPSS 20.00 software for Windows

China had the highest variation in percentage regarding the wine imports in 2018 compared to 2014, registering an increase of $79 \%$, from 3.8 million hl in 2014, to 6.9 million hl in 2018 . Nederland registered a growth of $11 \%$ regarding the wine imports, from 3,8 million hl in 2014 to 4.2 million hl in 2018 (Figure 7).

New Zeeland had the highest variation in percentage regarding the wine exports, registering an increase of $45 \%$, from 1.9 million hl in 2014, to 2.6 million hl in 2018. South Africa registered a growth of $25 \%$ regarding the wine exports, from 4.2 million hl in 2014 to 5.3 million hl in 2018 (Figure 8). 


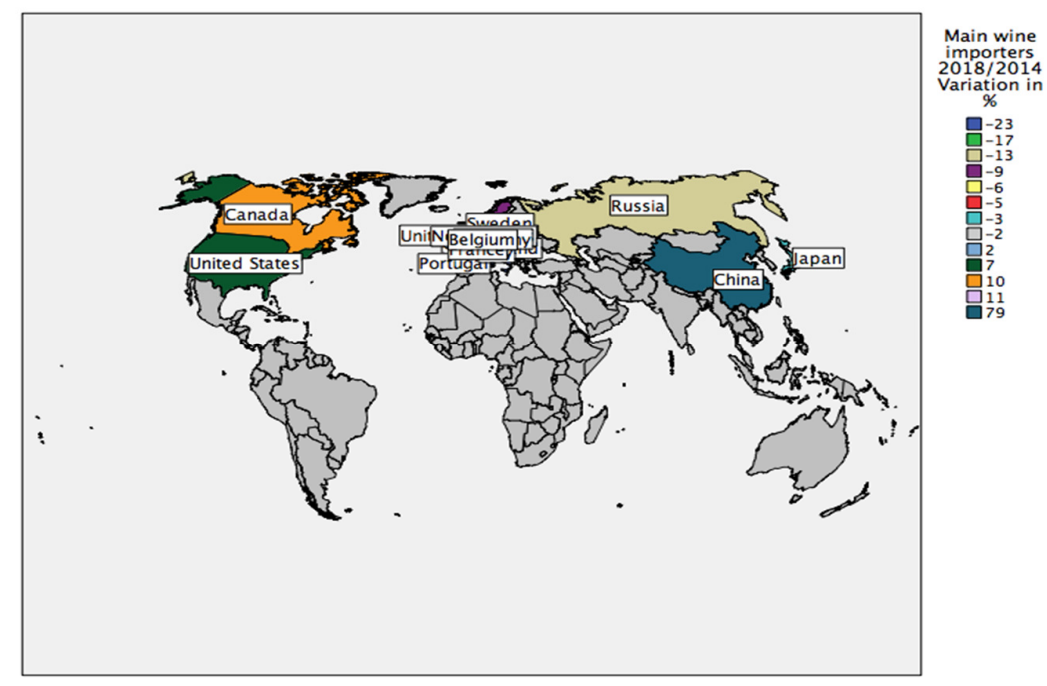

Figure 7. Main wine importers the worldwide level 2018/2014 [\%]

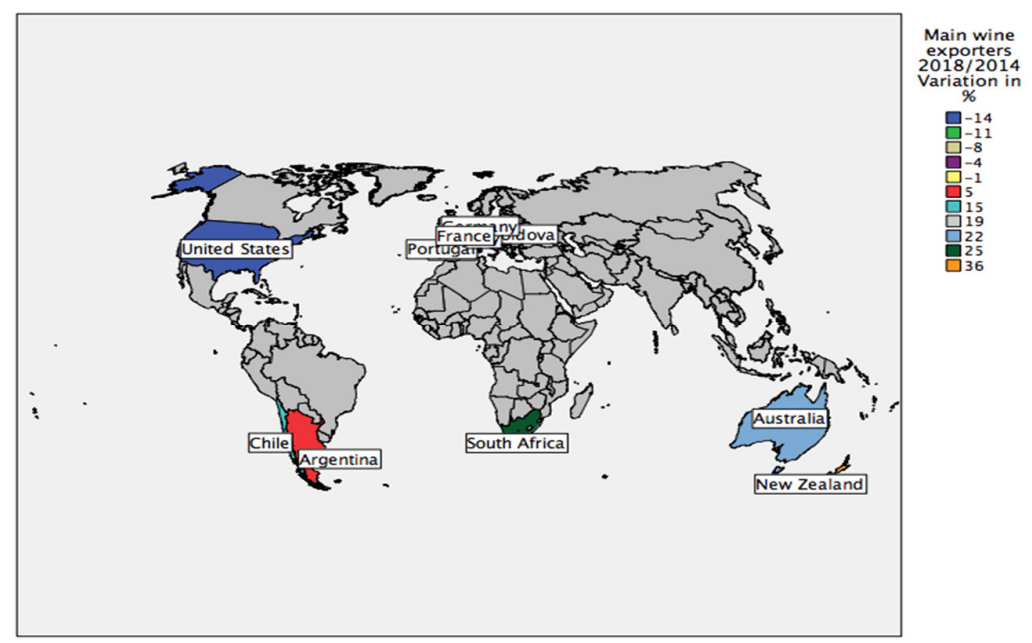

Figure 8. Main wine exporters the worldwide level 2018/2014 [\%]

Source: Authors' own processing with SPSS 20.00 software for Windows

\section{Results and Discussion}

Competitiveness growth of wine producers through the National Support Programme 2009-2013

In 2008, the reform of the wine market was organized in order to increase the competitiveness of the wine producers from the European Union, on one hand and, on the other hand, to achieve a balance between the demand and the supply of wine, according to Council Regulation (EC) No 479/2008.

However, in 2013, another reform took place, which aimed at harmonizing, rationalizing and simplifying the provisions of the Common Agricultural Policy (CAP), adopted during the previous reforms.

The National Support Programme was the instrument by which the member States had the opportunity to customize their financial support, depending on their specific situation. Till the present times, two support 
programmes were already implemented (2009-2013 and 2014-2018) and one program is still going on for the period 2019-2023.

Analysing the National Support Programme 2009-2013, the financial allocation was 5,315,092 thousand euro for 11 measures (Table 4):

- Single payment Scheme Support;

- Promotion;

- Restructuring and conversion of vineyard;

- Ongoing plans;

- Green harvesting;

- Mutual funds;

- Harvest insurance;

- Investments in enterprises;

- By-product distillation;

- Portable alcohol distillation;

- Crisis distillation;

- Use of concentrated grape must.

The data from the Table 4 reveals that the most substantial allocation is related to the measure aimed at restructuring and reconversion of the areas under vines, respectively the elimination of hybrid wines from plantations through conversion with noble vines.

Table 4. Financial allocation within National Support Programme 2009-2013

\begin{tabular}{|c|c|c|c|}
\hline No. crt. & Support measure & Financial allocation (thousand euro) & $(\%)$ \\
\hline 1. & Single Payment Scheme support & 509,715 & $9.59 \%$ \\
\hline 2. & Promotion & 623,747 & $11.74 \%$ \\
\hline 3.a & Restructuring and conversion of vineyard & $2,124,443$ & $39.97 \%$ \\
\hline 3.b & Ongoing Plans & 167,041 & $3.14 \%$ \\
\hline 4. & Green harvesting & 56,835 & $1.07 \%$ \\
\hline 5. & Mutual funds & 0 & $0.00 \%$ \\
\hline 6. & Harvest insurance & 129,117 & $2.43 \%$ \\
\hline 7. & Investment in enterprises & 552,941 & $10.40 \%$ \\
\hline 8. & By-product distillation & 451,699 & $8.50 \%$ \\
\hline 9. & Potable alcohol distillation & 358,509 & $6.75 \%$ \\
\hline 10. & Crisis distillation & 84,217 & $1.58 \%$ \\
\hline \multirow[t]{2}{*}{11.} & Use of concentrated grape must & 256,828 & $4.83 \%$ \\
\hline & Total & $5,315,092$ & $100.00 \%$ \\
\hline
\end{tabular}

The phenomenon of replacing the hybrid vine surface with rooted grafts led to plantations with noble vines, as well as to the replacement of old vines with those from modern new clones. This measure had a major contribution to the rejuvenation of the vineyard heritage and to the modernization of its structure, improving the structure of the grape varieties based on the market requirements. This can be strengthened by the fact that a vine plantation remains in exploitation for more than 40 years.

The European Union member states took advantage of the financial funds allocated to the National Support Programme 2009-2013, especially Italy, Spain and France, which together spent $78.72 \%$ of the total amount for this programme (Figure 9).

The results of the National Support Programme 2009-2013 at the level of the European Union countries were (Figure 10): 
- An area of 307,979 ha was reconverted;

- An initial budget of 2,291,484 thousand euro, majorated to 2,343,105 thousand ha;

- An average financial allocation per ha of 7,608 euro/ ha.

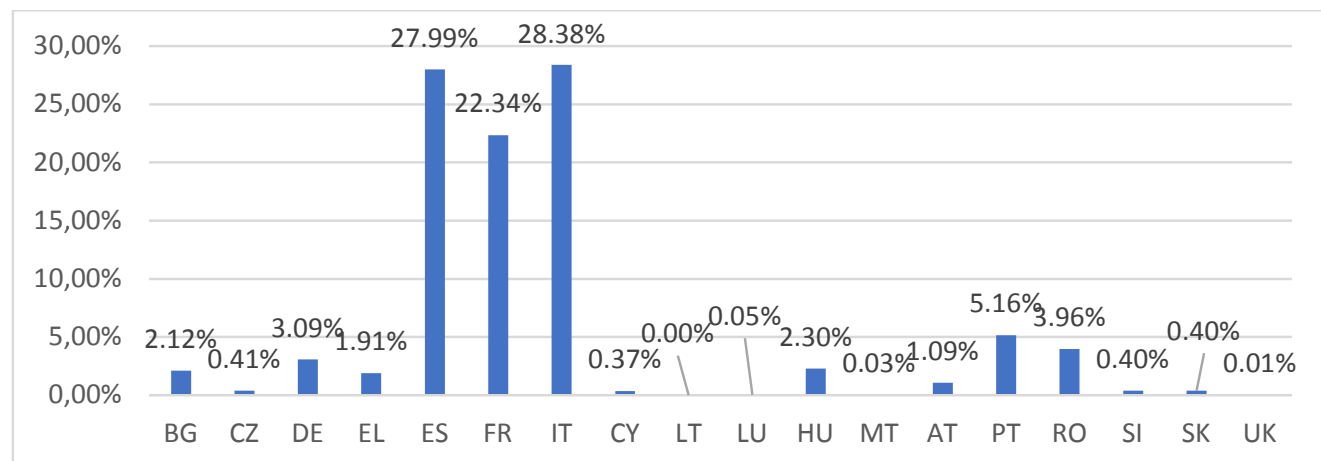

Figure 9. Financial funds allocated to the National Support Programme 2009-2013 by EU member states [\%]

Source: Authors' own analysis, https://ec.europa.eu/info/food-farming-fisheries/farming/facts-andfigures/markets/overviews/market-observatories/wine\#overview, accessed on 10.03.2020

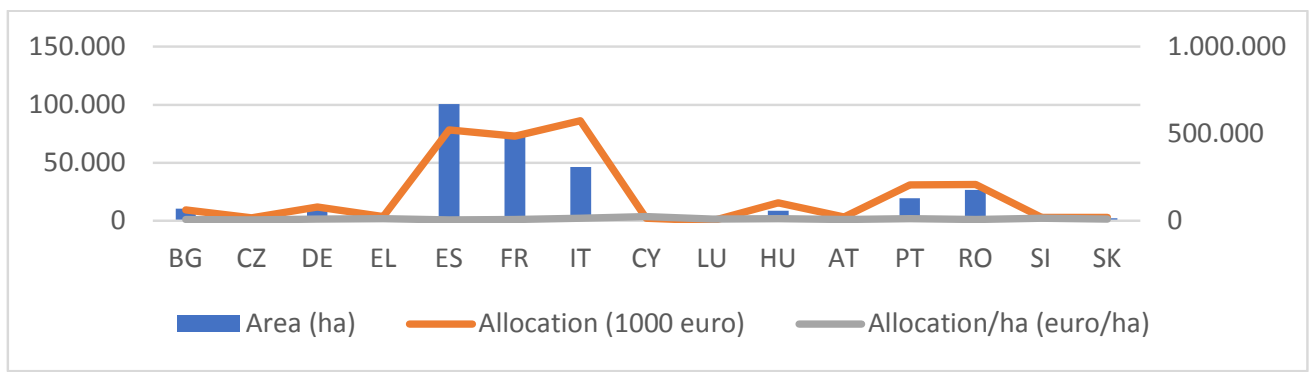

Figure 10. Results of the National Support Programme 2009-2013 by EU member states [\%]

Source: Authors' own analysis, https://ec.europa.eu/infolfood-farming-fisheries/farming/facts-andfigures/markets/overviews/market-observatories/wine\#loverview, accessed on 10.03.2020

For Romania, the results of the implementation of the National Support Programme 2009-2013 were (bttps://ec.europa.eu/info/food-farming-fisheries/farming/facts-and-figures/markets/overviews/marketobservatories/wine\#overview, accessed on 10.03.2020):

- An initial budget for restructuring and reconversion of 205,232 thousand euro;

- A final financial allocation of 206,569 thousand euro;

- A reconverted area of $26,704 \mathrm{ha}$;

- An average financial allocation per ha of 7,736 euro/ha.

Competitiveness growth of wine producers through the National Support Programme 2014-2018

Analysing the National Support Programme 2014-2018, the financial allocation was 6,241,206 thousand euro for 9 measures (Table 5):

- Single payment Scheme Support;

- Promotion;

- Restructuring and conversion;

- Replanting of vineyards for health or phytosanitary;

- Green harvesting;

- Mutual funds; 
- Harvest insurance;

- Investments in enterprises;

- Innovation;

- By-product distillation.

Table 5. Financial allocation within National Support Programme 2014-2018

\begin{tabular}{|c|l|l|l|}
\hline No. crt. & \multicolumn{1}{|c|}{ Support measure } & Financial allocation (thousand euro) & \multicolumn{1}{c|}{$(\%)$} \\
\hline 1. & Single Payment Scheme support & 735,295 & $9.59 \%$ \\
\hline 2. & Promotion & $1.094,112$ & $11.74 \%$ \\
\hline $3 . \mathrm{a}$ & Restructuring and conversion & $2.654,545$ & $39.97 \%$ \\
\hline $3 . \mathrm{b}$ & Replanting of vineyards for health or phytosanitary & 1,440 & $3.14 \%$ \\
\hline 4. & Green harvesting & 23,930 & $1.07 \%$ \\
\hline 5. & Mutual funds & 0 & $0.00 \%$ \\
\hline 6. & Harvest insurance & 129,657 & $2.43 \%$ \\
\hline 7. & Investment in enterprises & $1.200,467$ & $10.40 \%$ \\
\hline 8. & Innovation & 1,010 & $8.50 \%$ \\
\hline 9. & By-product distillation & 400,750 & $6.75 \%$ \\
\hline & Total & $\mathbf{6 . 2 4 1 , 2 0 6}$ & $\mathbf{1 0 0 . 0 0 \%}$ \\
\hline $\begin{array}{l}\text { Source: Authors own analysis, bttps://ec.europa.eu/info/food-farming-fisheries/farming/facts-and- } \\
\text { figures/markets/overviews/market-observatories/wine\#toverview, accessed on } 10.03 .2020\end{array}$
\end{tabular}

The European Union member states took advantage of the financial funds allocated to the National Support Programme 2014-2018, especially Italy, Spain and France, which together spent 77.76\% of the total amount for this programme (Figure 11).

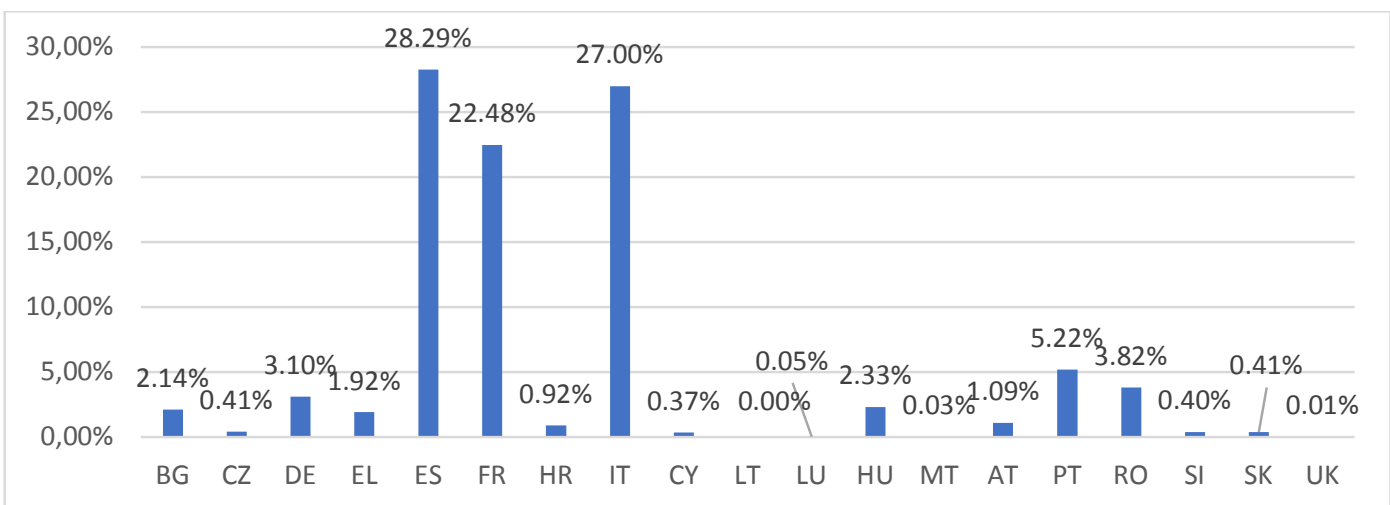

Figure 11. Financial funds allocated to the National Support Programme 2014-2018 by EU member states [\%] Source: Authors' own analysis, https:/lec.europa.eu/info/food-farming-fisheries/farming/facts-andfigures/markets/overviews/market-observatories/wine\#toverview, accessed on 10.03.2020

The results of the National Support Programme 2014-2018 at the level of the European Union countries are (Figure 12):

- An area of 385,171 ha was reconverted;

- An initial budget of 2,655,985 thousand euro, majorated to 2,654,812 thousand ha;

- An average financial allocation per ha of 6,894 euro/ ha. 


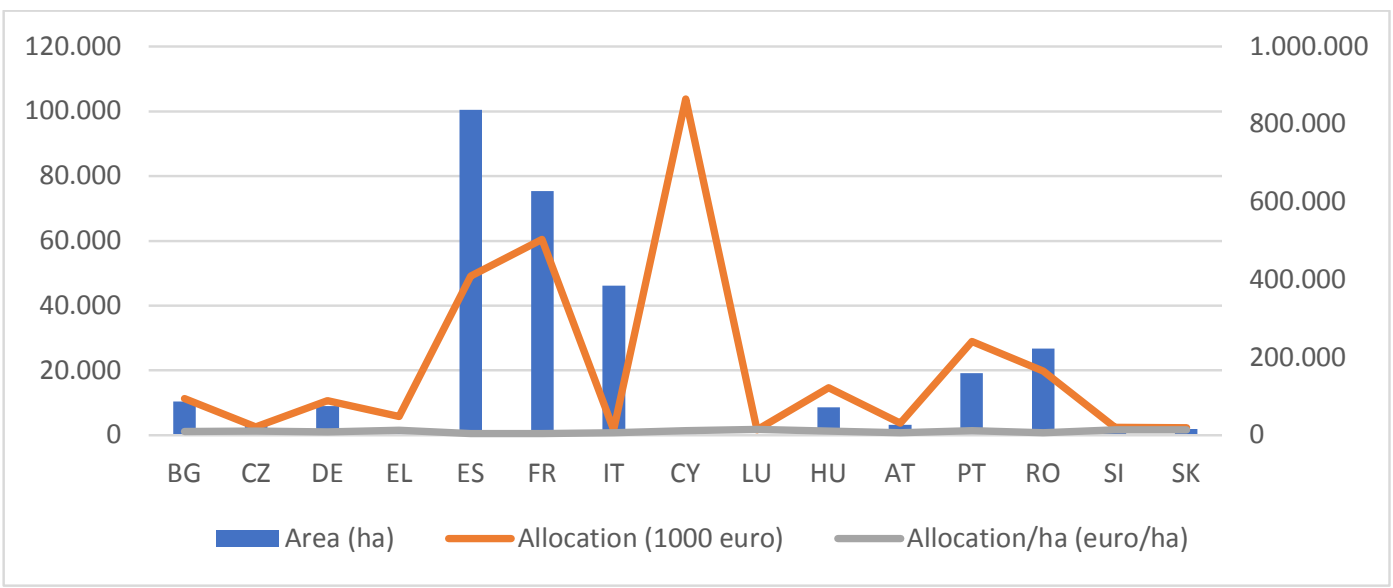

Figure 12. Results of the National Support Programme 2014-2018 by EU member states [\%]

Source: Authors' own analysis, https:/lec.europa.eu/info/food-farming-fisheries/farming/facts-and-

figures/markets/overviews/market-observatories/wine\#toverview, accessed on 10.03.2020

For Romania, the results of the implementation of the National Support Programme 2014-2018 were (bttps://ec.europa.eu/info/food-farming-fisheries/farming/facts-and-figures/markets/overviews/marketobservatories/wine\#overview, accessed on 10.03.2020):

- An initial budget for restructuring and reconversion of 191,050 thousand euro;

- A final financial allocation of 164,915 thousand euro;

- A reconverted area of 23,186 ha;

- An average financial allocation per ha of 7,113 euro/ha.

Competitiveness growth of wine producers through the National Support Programme 2019-2023

Analysing the National Support Programme 2019-2023, the financial allocation was 6,041,436 thousand euro for 9 measures (Table 6):

- Single payment Scheme Support;

- Promotion and Information;

- Restructuring and conversion;

- Replanting of vineyards for health or phytosanitary;

- Green harvesting;

- Mutual funds;

- Harvest insurance;

- Investments in enterprises;

- Innovation;

- By-product distillation.

The European Union member states took advantage of the financial funds allocated to the National Support Programme 2019-2023, especially Spain, Italy and France, which together spent $80.33 \%$ of the total amount for this programme at $30^{\text {th }}$ of June 2020 (Figure 13). 
Table 6. Financial allocation within National Support Programme 2019-2023

\begin{tabular}{|l|l|l|l|}
\hline No. crt. & \multicolumn{1}{|c|}{ Support measure } & $\begin{array}{c}\text { Financial allocation } \\
\text { (thousand euro) }\end{array}$ & \multicolumn{1}{|c|}{$\%$} \\
\hline 1. & Single Payment Scheme support & 719,295 & $11.91 \%$ \\
\hline 2. & Promotion and Information & $1,132,439$ & $18.74 \%$ \\
\hline $3 . \mathrm{a}$ & Restructuring and conversion & $2,274,724$ & $37.65 \%$ \\
\hline $3 . \mathrm{b}$ & Replanting of vineyards for health or phytosanitary & 2,500 & $0.04 \%$ \\
\hline 4. & Green harvesting & 28,500 & $0.47 \%$ \\
\hline 5. & Mutual funds & 0 & $0.00 \%$ \\
\hline 6. & Harvest insurance & 15,927 & $0.26 \%$ \\
\hline 7. & Investment in enterprises & $1,414,124$ & $23.41 \%$ \\
\hline 8. & Innovation & 975 & $0.02 \%$ \\
\hline 9. & By-product distillation & $\mathbf{6 5 2 , 9 5 2}$ & $7.50 \%$ \\
\hline & Total & $\mathbf{6 , 4 3 6}$ & $\mathbf{1 0 0 . 0 0 \%}$ \\
\hline
\end{tabular}

Source: Authors' own analysis, https://ec.europa.eu/info/food-farming-fisheries/farming/facts-andfigures/markets/overviews/market-observatories/wine\#overview, accessed on 10.03.2020

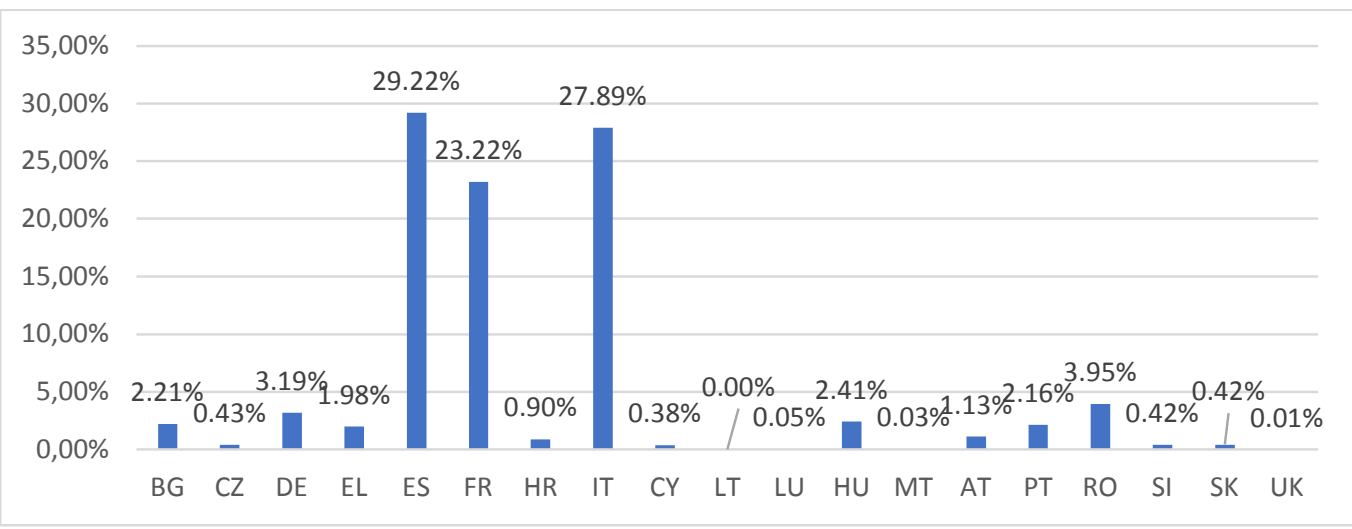

Figure 13. Financial funds allocated to the National Support Programme 2014-2018 by EU member states [\%]

Source: Authors' own analysis, https:/lec.europa.eu/info/food-farming-fisheries/farming/facts-and-

figures/markets/overviews/market-observatories/wine\#loverview, accessed on 10.03.2020

\section{Competitiveness of wine producers from Romania}

Romania is an important European country from the point of view of wine industry, the various wines it produces are known for their quality. With an area of around 180,000 ha cultivated with vines which, in 2016 , represented $1.42 \%$ of its agricultural area and $2.28 \%$ of arable area, Romania ranks the $5^{\text {th }}$ position in the European Union, after Spain, Italy, France and Portugal. (bttps://ec.europa.eu/info/food-farmingfisheries/farming/facts-and-figures/markets/overviews/market-observatories/wine\#toverview, accessed on 10.03.2020)

According to the data of the National Institute of Statistics (INS), the total area occupied by vineyards decreased by $5.40 \%$, from 187,629 ha in 2007 to 177,497 ha in 2018 (Figure 14).

Analysing the area under productive hybrid vines, we can observe a negative trend during the analysed period, as a result of the implementation of the National Support Programme for viticulture 2007-2013 and the National Support Program 2014-2018 for Romania in the wine sector.

The decrease of the areas under hybrid vineyards leads to the premises of qualitative development of the Romanian wine market, also sustained by the favourable legislative framework to the increase in areas under grafted vines. 


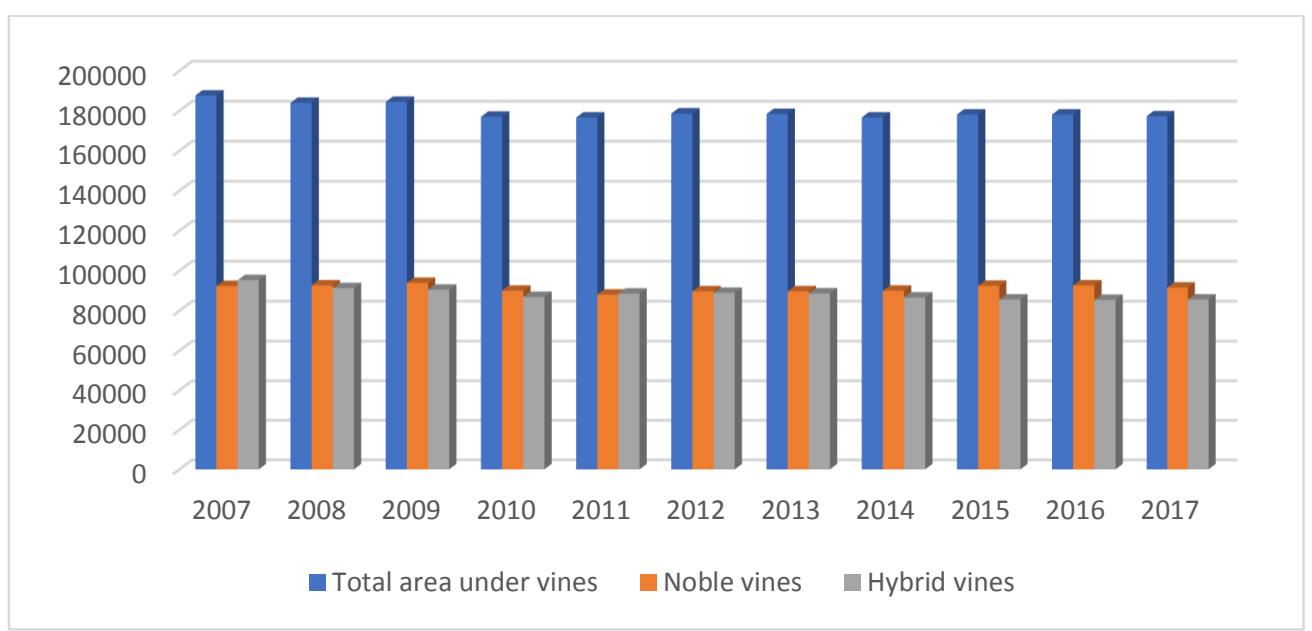

Figure 14. Evolution of the areas under productive vines in Romania 2007-2018 [ha]

Source: Authors' own analysis, The Statistical Yearbook of Romania, 2007-2018

\section{Conclusions}

This study explores the determinants of vine and wine industry, by analysing the impact of the National Support Programmes 2009-2013; 2014-2018; 2019-2023. The National Support Programme was the instrument by which the member States had the opportunity to customize their financial support, depending on their specific situation. Till the present times, two support programmes were already implemented (20092013 and 2014-208) and one program is still in progress for the period 2019-2023. Romania is an important European country from the point of view of wine industry, the various wines it produces are known for their quality. However, the countries that took the most of the advantage of the financial funds allocated through the National Support Programmes, were: Italy, Spain and France, which together spent more than $70 \%$ of the total amount for each of these programs.

\section{Authors' Contributions}

Conceptualization: NM, GL, MMT and CD; Formal analysis: NM, GL, MMT and CD; Methodology: NM, GL, MMT and CD; Validation: NM, GL, MMT and CD; Writing - original draft: NM and CD; Writing - review and editing: RL and MMT. All authors read and approved the final manuscript.

\section{Acknowledgements}

This research received no specific grant from any funding agency in the public, commercial, or not-forprofit sectors.

\section{Conflict of Interests}

The authors declare that there are no conflicts of interest related to this article. 


\section{References}

Anderson K, Nelgen S (2011). Global Wine Markets 1961-2009: A statistical compendium. The university of Adelaide Press. Retrieved 2020 March 01 from https://www.adelaide.edu.au/press/titles/global-wine

Andreyeva T, Long MW, Brownell KD (2010). The impact of food prices on consumption: A systematic review of research on the price elasticity of demand for food. American Journal of Public Health 100(2):216-222.

Asgeirsdottir TL, Corman H, Noonan K, Olafsdottir P, Reichman NE (2014). Was the economic crisis of 2008 good for Icelanders? Impact on health behaviors. Economics and Human Biology 13:1-19.

Casini L, Seghieri C, Tossisi F (2006). Wine consumer behaviour in selected points of sale of the Italian major retailing trade. Proceedings of the $3^{\text {rd }}$ International Wine Business and Research Conference. Montpelier pp 6-8.

Contini C, Romano C, Scozzafava G, Boncinelli F, Casini L (2015). Wine consumption and sales strategies: The evolution of Mass Retail Trading in Italy. Wine Economics and Policy 4:116-127. http://dx.doi.org/10.1016/j.wep.2015.12.001

DG Agri. Retrieved 2020 March 12 from https://agridata.ec.europa.eu/extensions/DashboardWine/WineProduction.html

Duquenne MN, Vlontzos G (2014). The impact of the Greek crisis on the consumers' behavior: some initial evidences? British Food Journal 116(6):890-903.

EU Wine Market Observatory. Retrieved 2020 March 10 from https:/lec.europa.eu/info/food-farmingfisheries/farming/facts-and-figures/markets/overviews/market-observatories/wine\#overview

Fikfak A, Spalevic V, Kosanovic S, Popovic SGDjurovic M, Konjar M (2017). Land use development of vineyards in Goriska Bdra, Slovenia. Notulae Botanicae Horti Agrobotanici 45(2):611-622. DOI:10.15835/nbha45210855

Hammervoll T, Mora P, Toften K (2014). The financial crisis and the wine industry; the performance of niche firms versus mass-market firms. Wine Economics and Policy 3(2):1033-1049.

Hollebeek LD, Jaeger SR, Brodie RJ, Balemi A (2007). The influence of involvement on purchase intention for new world wine. Food Quality Preference 18(8):1033-1049.

International Organisation of Vine and Wines (2019). Retrieved 2020 March 10 from http://www.oiv.int/public/medias/6782/oiv-2019-statistical-report-on-world-vitiviniculture.pdf

Jover AJV, Montes FJL, Fuentes MDF (2004). Measuring perceptions of quality in food products: the case of red wine. Food Quality Preference 15(5):453-469.

Menna A, Walsh PR (2019). Assessing environments of commercialization of innovation for SMEs in the global wine industry: A market dynamics approach. Wine Economics and Policy 8:191-202. https://doi.org/10.1016/j.wep.2019.10.001

Murfatlar DOC (2020). Retrieved 2020 March 10 from https://domeniulbogdan.ro/blog/cum-clasificam-vinurile-si-cesoiuri-de-struguri-sunt-cele-mai-cautatel

Prosdocimi M, Cerdà A, Taroli P (2016). Soil water erosion on Mediterranean vineyards: A review. Catena 141:1-21.

Ritchie C, Elliott G, Flynn M (2010). Buying wine on promotion is trading-up in UK supermarkets. International Journal and Wine Business Research 22(2):102-121.

Rotaru L, Filipov F, Mustea M, Stoleru V (2010). Influence of some “Terroir Viticole” factors on quantity and quality of grapes. Notulae Botanicae Horti Agrobotanici Cluj-Napoca 38(1):176-181.

Sammogia A, Arvola A, Bertazzoli A, Gurinovic M, Hendrixson V, Rivaroli S, Ruggeri A (2014). Offering low-cost healthy food: an exploration of food manufacturers 'and retailers' perspectives. International Food and Agribusiness Management Review 17:27-58.

Statistical Yearbook of Romania (2007-2018). Retrieved 2020 March 10 from www.insse.ro 
OPEN ACCESS

(c) (i)

The journal offers free, immediate, and unrestricted access to peer-reviewed research and scholarly work. Users are allowed to read, download, copy, distribute, print, search, or link to the full texts of the articles, or use them for any other lawful purpose, without asking prior permission from the publisher or the author.

License - Articles published in Notulae Botanicae Horti Agrobotanici Cluj-Napoca are Open-Access, distributed under the terms and conditions of the Creative Commons Attribution (CC BY 4.0) License. (C) Articles by the authors; UASVM, Cluj-Napoca, Romania. The journal allows the author(s) to hold the copyright/to retain publishing rights without restriction. 